\title{
Thermodesulfobacterium hydrogeniphilum sp. nov., a thermophilic, chemolithoautotrophic, sulfate-reducing bacterium isolated from a deep-sea hydrothermal vent at Guaymas Basin, and emendation of the genus Thermodesulfobacterium
}

\footnotetext{
${ }^{1}$ UMR 6539, Centre National de la Recherche Scientifique and Université de Bretagne Occidentale, Institut Universitaire Européen de la Mer, Place Nicolas Copernic, 29280 Plouzané, France

2 Laboratoire de Microbiologie et de Biotechnologie des Extrêmophiles, IFREMER, Centre de Brest, 29280 Plouzané, France

3 Portland State University, Biology Department, Portland, OR 97201, USA
}

\author{
Christian Jeanthon, ${ }^{1}$ Stéphane L'Haridon, ${ }^{1}$ Valérie Cueff, ${ }^{2}$ Amy Banta, ${ }^{3}$ \\ Anna-Louise Reysenbach ${ }^{3}$ and Daniel Prieur ${ }^{1}$
}

Author for correspondence: Christian Jeanthon. Tel: +33298 498 751. Fax: + 33298498705.
e-mail: Christian.Jeanthon@ univ-brest.fr

A thermophilic, non-spore-forming, marine, sulfate-reducing bacterium, strain $\mathrm{SL6}^{\top}$, was isolated from deep-sea hydrothermal sulfides collected at Guaymas Basin. The Gram-negative-staining cells occurred singly or in pairs as small, highly motile rods. The temperature range for growth was $50-80^{\circ} \mathrm{C}$ with an optimum at $75{ }^{\circ} \mathrm{C}$. The $\mathrm{pH}$ range for growth at $70^{\circ} \mathrm{C}$ was $6 \cdot 3-6 \cdot 8$, with an optimum at 6.5. The $\mathrm{NaCl}$ concentration range for growth was 5-55 $\mathrm{g} \mathrm{I}^{-1}$, with an optimum at $30 \mathrm{~g} \mathrm{I}^{-1} \cdot \mathrm{H}_{2}$ and $\mathrm{CO}_{2}$ were the only substrates for growth and sulfate reduction. However, growth was stimulated by several organic compounds. Sulfur, thiosulfate, sulfite, cystine, nitrate and fumarate were not used as electron acceptors. Pyruvate, lactate and malate did not support fermentative growth. Desulfoviridin was not detected. The $G+C$ content of the genomic DNA was $28 \mathrm{~mol} \%$. On the basis of 165 rRNA sequence analysis, strain SL6 $^{\top}$ is related to members of the genus Thermodesulfobacterium. However, the novel organism possesses phenotypic and phylogenetic traits that differ from those of its closest relatives. Therefore, it is proposed that this isolate, which constitutes the first marine representative of this genus, should be described as the type strain of a novel species, Thermodesulfobacterium hydrogeniphilum sp. nov. The type strain is SL6 ${ }^{\top}$ ( $=$ DSM $14290^{\top}=J C M 11239^{\top}$ ). Because of the phenotypic characteristics of the novel species, it is also proposed that the description of the genus Thermodesulfobacterium requires emendation.

Keywords: deep-sea hydrothermal vent, thermophile, Bacteria, Thermodesulfobacterium, sulfate reduction

\section{INTRODUCTION}

Phylogenetically diverse thermophilic sulfate-reducers have been isolated from both marine high-temperature environments, i.e. hydrothermal systems and deep

Published online ahead of print on 3 December 2001 as DOI 10.1099/ ijs.0.02025-0.

The GenBank/EMBL/DDBJ accession number for the $16 \mathrm{~S}$ rRNA sequence of strain $\mathrm{SLG}^{\top}$ is $A F 332514$. offshore petroleum reservoirs. Marine sulfate-reducing representatives of the domain Archaea are restricted to hyperthermophilic members of the genus Archaeoglobus (Stetter, 1992). This genus contains three validly described species, Archaeoglobus fulgidus (Stetter et al., 1987; Stetter, 1988), Archaeoglobus profundus (Burggraf et al., 1990) and Archaeoglobus veneficus (Huber et al., 1997). The sulfate-reducers A. fulgidus and $A$. profundus have been isolated from diverse deep petroleum reservoirs (Stetter et al., 1993; Beeder et al., 1994; L'Haridon et al., 1995) and deep-sea hydro- 
thermal vents at Guaymas Basin (Burggraf et al., 1990), whereas the sulfite-reducer $A$. veneficus has been found to occur in several chimney samples collected at the Mid-Atlantic Ridge $\left(23^{\circ} \mathrm{N}\right)$ and East Pacific Rise $\left(9^{\circ} \mathrm{N}\right)$. With the exception of Desulfotomaculum thermocisternum, a Gram-positive spore-former isolated from North Sea oil reservoir formation water (Nilsen et al., 1996), all the thermophilic, marine sulfate-reducers of the domain Bacteria described to date belong to the $\delta$-Proteobacteria. These are Thermodesulforhabdus norvegicus (Beeder et al., 1995) and Desulfacinum infernum (Rees et al., 1995), both of which were isolated from North Sea petroleum reservoirs, the hydrocarbon-degrading strain TD3, isolated from a deep-sea vent site in the Guaymas Basin (Rueter et al., 1994), Desulfacinum hydrothermale and a novel species belonging to the genus Thermodesulforhabdus, isolated from a marine, shallow-water hydrothermal vent site in the Aegean Sea (Sievert \& Kuever, 2000).

Members of the genus Thermodesulfobacterium are non-spore-forming, thermophilic, sulfate-reducing bacteria (Widdel, 1992) that branch deeply within the domain Bacteria (Olsen et al., 1994b; Castro et al., 2000). To date, no representatives of this genus have been isolated from marine, high-temperature habitats. The genus Thermodesulfobacterium includes three described species: Thermodesulfobacterium commune and Thermodesulfobacterium hveragerdense, respectively isolated from microbial mats in hot springs at Yellowstone National Park and in Iceland (Zeikus et al., 1983; Sonne-Hansen \& Ahring, 1999), and Thermodesulfobacterium thermophilum (Tao et al., 1996; De Vos \& Trüper, 2000) [previously named Desulfovibrio thermophilus by Rozanova \& Khudyakova (1974) and later reclassified illegitimately as Thermodesulfobacterium mobile by Rozanova \& Pivovarova (1988)], isolated from hot stratal water from a petroleum reservoir. These species have a relatively restricted type of nutrition and are incomplete oxidizers, using $\mathrm{H}_{2}$, lactate and pyruvate as electron donors for sulfate reduction.

In this paper, we describe the isolation and characterization of a novel thermophilic, sulfate-reducing isolate, strain SL6 ${ }^{\mathrm{T}}$, which was obtained from a deepsea hydrothermal vent site at Guaymas Basin.

\section{METHODS}

Sample collection. Hydrothermal chimneys and sediments were collected in 1991 from the Guaymas Basin hydrothermal vent field $\left(27^{\circ} 01^{\prime} \mathrm{N}, 111^{\circ} 24^{\prime} 30^{\prime \prime} \mathrm{W}\right)$ at a depth of $2000 \mathrm{~m}$, during the Guaynaut cruise. Using the port manipulator of the submersible Nautile, the samples were placed in the submersible insulated basket for the trip to the surface. Once they had been transferred on board, they were put into $50 \mathrm{ml}$ glass vials and flooded with a sterile solution of $3 \%(\mathrm{w} / \mathrm{v})$ sea salts (Sigma). The vials were then closed tightly with butyl rubber stoppers (Bellco), pressurized with $\mathrm{N}_{2}(100 \mathrm{kPa})$, reduced with sodium sulfide when required and stored at $4{ }^{\circ} \mathrm{C}$ until they were processed (recently).
Enrichment cultures and purification. Enrichments were performed anaerobically in 50 or $100 \mathrm{ml}$ vials respectively containing 10 or $20 \mathrm{ml}$ medium (Miller \& Wolin, 1974). The enrichment medium consisted of $\left(1^{-1}\right.$ distilled water $): 30 \mathrm{~g}$ sea salts (Sigma), $1 \mathrm{~g} \mathrm{NH}_{4} \mathrm{Cl}, 0.35 \mathrm{~g} \mathrm{KH}_{2} \mathrm{PO}_{4}, 3.46 \mathrm{~g}$ PIPES, $1 \mathrm{~g} \mathrm{NaHCO}_{3}, 2 \mathrm{~g}$ Difco yeast extract, $2 \mathrm{~g}$ Difco peptone, $1 \mathrm{~g}$ sodium acetate, $0.5 \mathrm{~g}$ cysteine hydrochloride, $1 \mathrm{ml}$ traceelement mixture (Widdel \& Bak, 1992), $30 \mathrm{mg}$ sodium tungstate, $0.5 \mathrm{mg}$ sodium selenate, $1 \mathrm{ml}$ vitamin mixture (Widdel \& Bak, 1992), $1 \mathrm{ml}$ thiamin solution (Widdel \& Bak, 1992), $0.05 \mathrm{mg}$ vitamin $B_{12}, 1 \mathrm{ml}$ growth-stimulating factors (Pfennig et al., 1981) and $1 \mathrm{mg}$ resazurin. The $\mathrm{pH}$ of the medium was adjusted to 6.5 using $5 \mathrm{M} \mathrm{HCl}$ before autoclaving. $\mathrm{H}_{2} / \mathrm{CO}_{2}(80: 20 ; 200 \mathrm{kPa})$ was used as the gas phase. Cultures were incubated at $65^{\circ} \mathrm{C}$ and the $\mathrm{pH}$ of the medium was readjusted after $1 \mathrm{~h}$ incubation. Enrichments that produced sulfide were subcultured into the same medium that had been solidified with $0.7 \%(\mathrm{w} / \mathrm{v})$ Phytagel by using shake dilution series (Widdel \& Bak, 1992). Tubes were incubated at $65^{\circ} \mathrm{C}$ for 7 days under a $\mathrm{H}_{2} / \mathrm{CO}_{2}$ atmosphere $(80: 20 ; 200 \mathrm{kPa})$ and colonies were then removed and subcultured until a pure culture was obtained. Purity was checked at $65^{\circ} \mathrm{C}$ aerobically in Marine broth (Difco) and anaerobically in Marine broth supplemented with $5 \mathrm{mM}$ glucose. Stock cultures of isolate SL6 ${ }^{\mathrm{T}}$ were stored in culture medium at $4{ }^{\circ} \mathrm{C}$. For long-term storage, pure cultures were stored at $-80{ }^{\circ} \mathrm{C}$ in the same medium containing $5 \%(\mathrm{w} / \mathrm{v})$ DMSO

Culture medium and conditions. Isolate $\mathrm{SL}^{\mathrm{T}}$ was routinely grown in the following medium containing $\left(1^{-1}\right.$ distilled water): $30 \mathrm{~g} \mathrm{NaCl}, 3 \mathrm{~g} \mathrm{MgCl}_{2} .2 \mathrm{H}_{2} \mathrm{O}, 4 \mathrm{~g} \mathrm{Na}_{2} \mathrm{SO}_{4}, 0.5 \mathrm{~g} \mathrm{KCl}$, $0.25 \mathrm{~g} \quad \mathrm{NH}_{4} \mathrm{Cl}, \quad 0.2 \mathrm{~g} \quad \mathrm{KH}_{2} \mathrm{PO}_{4}, \quad 3.46 \mathrm{~g}$ PIPES, $0.15 \mathrm{~g}$ $\mathrm{CaCl}_{2} \cdot 2 \mathrm{H}_{2} \mathrm{O}, 0.5 \mathrm{~g}$ Difco yeast extract, $1 \mathrm{mM}$ sodium acetate, $1 \mathrm{ml}$ trace-element mixture (Widdel \& Bak, 1992), $0.2 \mathrm{mg}$ sodium tungstate, $50 \mu \mathrm{g}$ sodium selenate, $1 \mathrm{ml}$ vitamin mixture (Widdel \& Bak, 1992), $1 \mathrm{ml}$ thiamin solution (Widdel \& Bak, 1992), 0.05 mg vitamin $\mathrm{B}_{12}, 1 \mathrm{ml}$ growthstimulating factors (Pfennig et al., 1981) and $1 \mathrm{mg}$ resazurin. The $\mathrm{pH}$ of the medium was adjusted to 6.5 using $5 \mathrm{M} \mathrm{HCl}$ before autoclaving. After autoclaving, the $\mathrm{pH}$ of the medium was readjusted to 6.5 at room temperature. $\mathrm{H}_{2} / \mathrm{CO}_{2}(80: 20$; $200 \mathrm{kPa}$ ) was used as the gas phase. Cultures were incubated at $70{ }^{\circ} \mathrm{C}$ and the $\mathrm{pH}$ of the medium was readjusted after $1 \mathrm{~h}$ incubation.

Determination of growth. Growth was monitored by measuring changes in turbidity at $600 \mathrm{~nm}$ by inserting anoxic culture tubes directly into a Spectronic 20D spectrophotometer (Bioblock). Direct cell counts were determined using cells stained with acridine orange and were counted by epifluorescence microscopy using an ocular grid (Hobbie et al., 1977). All growth experiments were performed in duplicate.

Determination of growth parameters. These experiments were performed without agitation. The influence of $\mathrm{pH}$ on growth was determined in the culture medium. The medium was adjusted to the desired $\mathrm{pH}$, measured at ambient temperature by injecting $10 \%(\mathrm{w} / \mathrm{v})$ sterile, anaerobic, stock solutions of $10 \%(\mathrm{w} / \mathrm{v}) \mathrm{NaHCO}_{3}$ and $8 \%(\mathrm{w} / \mathrm{v}) \mathrm{Na}_{2} \mathrm{CO}_{3}$. In order to determine the $\mathrm{NaCl}$ range for growth, the $\mathrm{NaCl}$ concentration was varied while the concentrations of the other inorganic components were maintained.

Determination of growth requirements. The following organic substrates were tested as electron donors [with $\mathrm{N}_{2} / \mathrm{CO}_{2}$ $(80: 20 ; 200 \mathrm{kPa})$ as the headspace] or carbon sources [with $\mathrm{H}_{2}(100 \% ; 100 \mathrm{kPa})$ as the headspace] in the presence of 
$20 \mathrm{mM}$ sulfate (added substrate concentrations, in $\mathrm{mM}$ or $\mathrm{w} / \mathrm{v}$, are given in parentheses): acetate (15), formate (15), methanol $(0.5 \%)$, monomethylamine $(0 \cdot 2 \%)$, malate $(10)$, propionate (10), glutamate (5), fumarate (10), tryptone $(0.1 \%)$, peptone $(0.1 \%)$, valerate $(5)$, isovalerate $(5)$, butyrate (10), isobutyrate (5), 2-methylbutyrate (5), 3-methylbutyrate (5), glucose (5), fructose (5), ethanol (10), propanol (5), pyruvate $(10)$, lactate $(20)$, succinate $(10)$, caprylate $(2 \cdot 5)$, caproate (5), caprate $(2 \cdot 5)$ and heptanoate (5). These substrates were tested at the same concentrations as stimulating agents for growth, with $\mathrm{H}_{2} / \mathrm{CO}_{2}(80: 20 ; 200 \mathrm{kPa})$ as the headspace. Ammonium chloride $(5 \mathrm{mM})$, nitrate $(5 \mathrm{mM})$, peptone $(0 \cdot 1 \%)$ and tryptone $(0 \cdot 1 \%)$ were tested for suitability as nitrogen sources. Elemental sulfur $(1 \%)$, thiosulfate $(10 \mathrm{mM})$, sulfite $(2 \mathrm{mM})$, cystine $(1 \%)$, nitrate $(5 \mathrm{mM})$ and fumarate $(10 \mathrm{mM})$ were tested as potential electron acceptors in sulfate-free medium.

Desulfoviridin. The presence of desulfoviridin was determined by adding $\mathrm{NaOH}$ to a resuspended pellet of cells and viewing the preparation under UV light, as described by Postgate (1959). Desulfovibrio giganteus (DSM 4123 ${ }^{\mathrm{T}}$ ) was used as a positive control.

Antibiotic susceptibility. The sensitivity of strain SL6 ${ }^{\mathrm{T}}$ to ampicillin, chloramphenicol, kanamycin, penicillin $\mathrm{G}$, streptomycin, tetracycline and rifampicin (Sigma) was tested at concentrations of $25,50,100$ and $200 \mu \mathrm{g} \mathrm{ml}^{-1}$.

Light and electron microscopy. An Olympus BH-2 microscope equipped with an Olympus OM-2 camera was used routinely to observe the bacteria and to obtain photomicrographs. Gram staining was carried out as described by Conn et al. (1957). For negative staining, $20 \mu \mathrm{l}$ of a bacterial suspension fixed with $2 \%(\mathrm{w} / \mathrm{v})$ glutaraldehyde was dropped on Formvar-/carbon-coated grids (400 mesh) and stained with $4 \%(\mathrm{w} / \mathrm{v})$ uranyl acetate. Electron micrographs were taken using a Philips model EM201 transmission electron microscope with an acceleration voltage of $80 \mathrm{kV}$.

$\mathrm{H}_{2} \mathrm{~S}$ production. $\mathrm{H}_{2} \mathrm{~S}$ production was evaluated by adding $500 \mu \mathrm{l}$ of a solution of $\mathrm{CuSO}_{4}(5 \mathrm{mM})$ and $\mathrm{HCl}(50 \mathrm{mM})$ to a $250 \mu \mathrm{l}$ culture grown at $70^{\circ} \mathrm{C}$. The dark-brown precipitate, demonstrating the presence of sulfide, was compared with uninoculated medium incubated under the same conditions.

DNA base composition. Genomic DNA of strain SL6 ${ }^{\mathrm{T}}$ was isolated by using the procedure described by Charbonnier \& Forterre (1994). The DNA was purified on a caesium chloride gradient (Sambrook et al., 1989) and purity was checked spectrophotometrically. The $\mathrm{G}+\mathrm{C}$ content of the DNA was determined from the melting point, according to the method of Marmur \& Doty (1962), using Escherichia coli DNA $(\mathrm{G}+\mathrm{C}$ content $52 \mathrm{~mol} \%)$, Clostridium perfringens DNA (24 mol \%) and Micrococcus luteus DNA (73 mol \%) (all from Sigma) as standards.

PCR amplification and sequencing of the 16S rDNA. The 16S rRNA genes from strain SL6 ${ }^{\mathrm{T}}$ genomic DNA were amplified, with a PCR, in reactions containing $50 \mathrm{mM} \mathrm{KCl}, 30 \mathrm{mM}$ Tris $/ \mathrm{HCl}(\mathrm{pH} 8.3), 1.5 \mathrm{mM} \mathrm{MgCl}_{2}, 200 \mu \mathrm{M}$ each of dATP, dCTP, dGTP and dTTP, 0.05\% Igepal (Sigma), 1 U Taq polymerase and 20 pmol of each primer (5'-AGAGTTTGATCCTGGCTCAG-3' and 5'-GGTTACCTTGTTACGACTT-3', corresponding to positions 8-27 and 1492-1510 in the $E$. coli rRNA sequence; Brosius et al., 1978). The sample was denatured by heating the reaction mixture at $94{ }^{\circ} \mathrm{C}$ for 2 min and the thermal profile then consisted of 30 cycles of annealing at $50{ }^{\circ} \mathrm{C}$ for $30 \mathrm{~s}$, extension at $72^{\circ} \mathrm{C}$ for $90 \mathrm{~s}$ and denaturation at $94{ }^{\circ} \mathrm{C}$ for $30 \mathrm{~s}$. A final extension step was carried out at $72{ }^{\circ} \mathrm{C}$ for $10 \mathrm{~min}$. PCR products (approx.
$1500 \mathrm{bp}$ ) were purified by using the PCRpure Spin kit (ISC) and cloned into the vector pCR2.1 by using the TOPO-TA cloning kit (Invitrogen). Plasmid DNA was prepared using an alkaline-lysis method (Inc. Perfect Prep kit). Sequencing reactions were performed using the ABI PRISM BigDye Terminator Cycle Sequencing kit and an ABI 310 Genetic Analyzer (PE Biosystems) according to the manufacturer's protocol. The complete sequence on both strands was obtained by using vector-specific primers and a suite of $16 \mathrm{~S}$ rDNA-specific primers to generate an overlapping set of sequences that were assembled into one contiguous sequence. The PCR product was also sequenced directly and no polymorphisms were observed.

Phylogenetic analysis of the rDNA genes. The $16 \mathrm{~S}$ rDNA sequences were aligned manually with the sequences of representatives of related genera obtained from the Ribosomal Database Project (Maidak et al., 1999) or from recent GenBank releases. The secondary structure was used as a guide to ensure that only homologous regions were compared. In total, 1451 nucleotides were sequenced and 1241 were used in the phylogenetic analysis. Distance trees were constructed by using the least-squares algorithm of De Soete (1983). Maximum-likelihood trees and corresponding bootstrap proportions were constructed by using the program fastDNAmL (Olsen et al., 1994a). Bootstrap values were obtained for 100 replicate trees.

\section{RESULTS AND DISCUSSION}

\section{Enrichment and isolation}

The enrichment medium used in this study was originally designed to enable investigation of the presence of novel thermophilic methanogens in Guaymas Basin hydrothermal samples. Chimney and sediment suspensions $(1 \mathrm{ml})$ were inoculated into $10 \mathrm{ml}$ enrichment medium and incubated at 65 and $80{ }^{\circ} \mathrm{C}$ in $50 \mathrm{ml}$ vials with $\mathrm{H}_{2} / \mathrm{CO}_{2}$ as the gas phase $(80: 20$; $200 \mathrm{kPa}$ ) without shaking. At $80^{\circ} \mathrm{C}$ within $2-3$ days, five of the samples showed growth of coccoid cells that fluoresced intense green at $420 \mathrm{~nm}$. The hyperthermophilic strains isolated from these cultures were further identified as methanogens (Jeanthon et al., 1999). An intense $\mathrm{H}_{2} \mathrm{~S}$ odour developed after 8 days in one of the cultures incubated at $65^{\circ} \mathrm{C}$. The prevailing organism in this enrichment culture, a motile, rod-shaped bacterium designated strain $\mathrm{SL6}^{\mathrm{T}}$, was isolated and studied in detail.

\section{Phenotypic characteristics}

Cells of strain SL6 ${ }^{\mathrm{T}}$ appeared as small rods, approximately $0.5-0.8 \mu \mathrm{m}$ long and $0.4-0.5 \mu \mathrm{m}$ wide (Fig. 1a, b), and stained Gram-negative. They occurred singly or in pairs. Each cell appeared to be highly motile by means of a single polar flagellum (Fig. 1b). In the stationary growth phase, some rods became longer and chains containing up to five to six cells were formed. Moreover, round, poorly refractile bodies $(1-1.5 \mu \mathrm{m}$ in diameter) were observed occasionally in stationary-phase cultures. Spores were not produced.

Strain SL6 ${ }^{\mathrm{T}}$ grew at temperatures between 50 and $80^{\circ} \mathrm{C}$, with an optimum around $75^{\circ} \mathrm{C}$, whereas no 


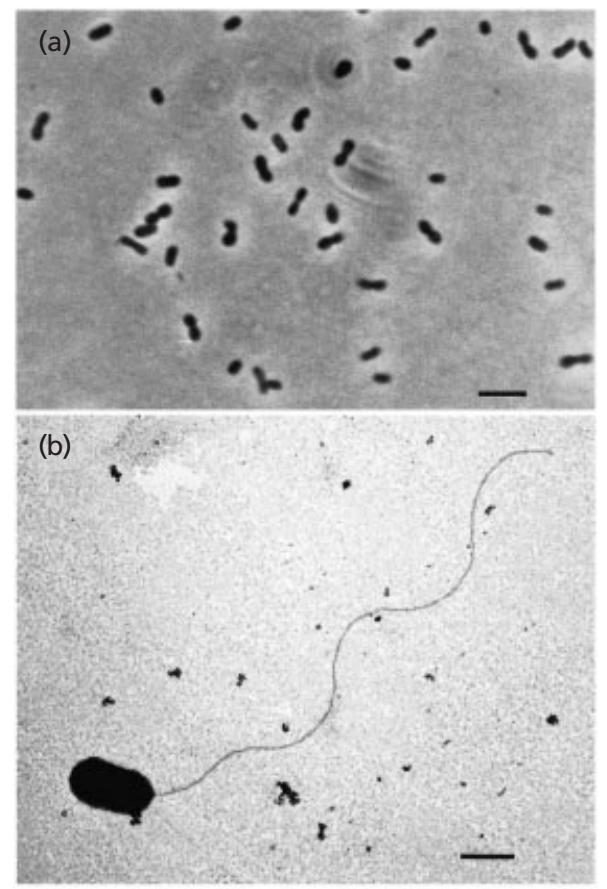

Fig. 1. (a) Phase-contrast micrograph of strain $\mathrm{SL6}^{\top}$; bar, $5 \mu \mathrm{m}$. (b) Electron micrograph of a negatively stained cell of strain SL6 ${ }^{\top}$ showing a single polar flagellum; bar, $500 \mathrm{~nm}$.

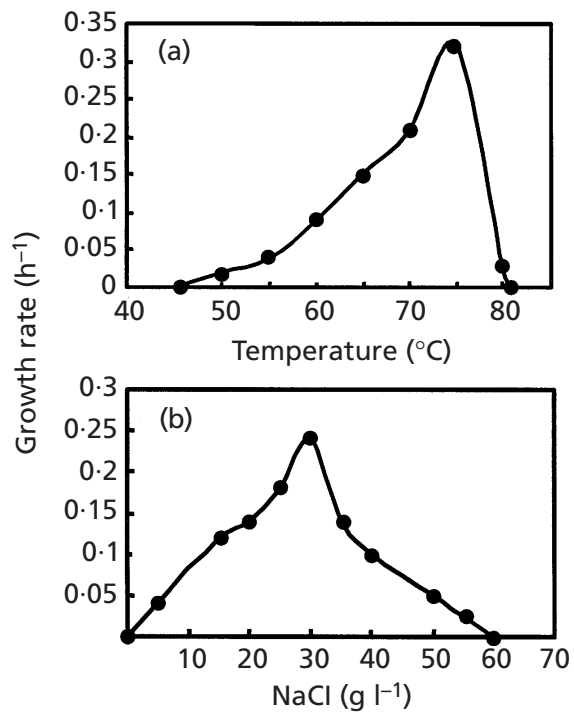

Fig. 2. Effect of (a) temperature (in the presence of $30 \mathrm{~g} \mathrm{NaCl}$ $\mathrm{I}^{-1}$ at $\mathrm{pH} 6 \cdot 5$ ) and (b) $\mathrm{NaCl}$ concentration (at $70^{\circ} \mathrm{C}$ and at $\mathrm{pH} \mathrm{6.5)}$ on growth of strain $\mathrm{SLG}^{\top}$.

growth was detected at 45 or $81{ }^{\circ} \mathrm{C}$ (Fig. 2a). Growth was observed between $\mathrm{pH} 6.3$ and 6.8 , the optimum being around $\mathrm{pH} 6 \cdot 5$ (data not shown). No growth was detected at $\mathrm{pH} 6.2$ or 6.9 after $96 \mathrm{~h}$ incubation at $70{ }^{\circ} \mathrm{C}$. Growth could be observed at $\mathrm{NaCl}$ concentrations ranging from 5 to $55 \mathrm{~g} \mathrm{l}^{-1}$ (Fig. 2b), the optimum being approximately $30 \mathrm{~g}^{-1}$. No growth was observed at
$\mathrm{NaCl}$ concentrations of 0 or $60 \mathrm{~g} \mathrm{l}^{-1}$ after $96 \mathrm{~h}$ incubation at $70^{\circ} \mathrm{C}$. Under optimal growth conditions (i.e. optimal temperature, $\mathrm{pH}$ and $\mathrm{NaCl}$ concentration) without agitation, the doubling time of strain SL6 ${ }^{\mathrm{T}}$ was around $3 \cdot 1 \mathrm{~h}$.

The novel isolate was a strictly anaerobic organism, growing chemolithoautotrophically by sulfate reduction using molecular hydrogen as the electron donor. Hydrogen was essential for growth. Growth was accompanied by exponential $\mathrm{H}_{2} \mathrm{~S}$ production that followed the growth curve (data not shown). Growth was prevented in the presence of low levels of oxygen. Of the alternative possible electron acceptors tested in combination with $\mathrm{H}_{2}$ as the electron donor, sulfur, thiosulfate, cystine, sulfite, nitrate and fumarate could not be used by strain $\mathrm{SL6}^{\mathrm{T}}$. In the presence of $\mathrm{H}_{2}, \mathrm{CO}_{2}$ and sulfate, the lag phase was reduced when acetate (even at $1 \mathrm{mM}$ ), fumarate, 3-methylbutyrate, glutamate, yeast extract, peptone or tryptone was added to the culture medium. Under the same conditions, glucose, fructose and valerate had no effect on growth, whereas malate, ethanol, formate, isovalerate, propionate, butyrate, isobutyrate, 2-methylbutyrate, propanol and succinate were slightly inhibitory. Growth was inhibited completely in the presence of pyruvate, lactate, caprylate, caproate, caprate or heptanoate. No growth was observed when the following compounds were used as electron donors [with $\mathrm{N}_{2} / \mathrm{CO}_{2}(80: 20 ; 200 \mathrm{kPa})$ as the headspace] or as carbon sources [with $\mathrm{H}_{2}(100 \% ; 100 \mathrm{kPa})$ as the headspace] in the presence of $20 \mathrm{mM}$ sulfate: acetate, formate, methanol, monomethylamine, malate, propionate, glutamate, fumarate, tryptone, peptone, valerate, isovalerate, butyrate, isobutyrate, 2-methylbutyrate, 3-methylbutyrate, glucose, fructose, ethanol, propanol, pyruvate, lactate, succinate, caprylate, caproate, caprate and heptanoate. No fermentative growth was obtained on pyruvate, lactate or malate. Ammonium was used preferentially as the nitrogen source, but growth also occurred in the presence of nitrate, peptone or tryptone. Desulfoviridin was absent in strain SL6 ${ }^{\mathrm{T}}$.

The growth of strain SL6 ${ }^{\mathrm{T}}$ was inhibited by ampicillin, chloramphenicol and rifampicin at the lowest concentration tested $\left(25 \mu \mathrm{g} \mathrm{ml}^{-1}\right)$. The organism did not grow in the presence of tetracycline $\left(50 \mu \mathrm{g} \mathrm{ml}^{-1}\right)$. Growth occurred in the presence of penicillin $G$ $\left(100 \mu \mathrm{g} \mathrm{ml}^{-1}\right)$, kanamycin and streptomycin (each at $\left.200 \mu \mathrm{g} \mathrm{ml}^{-1}\right)$.

\section{DNA base composition}

The $\mathrm{G}+\mathrm{C}$ content of the DNA of strain $\mathrm{SL6}^{\mathrm{T}}$, determined using the thermal denaturation method, was $28 \mathrm{~mol} \%$.

\section{$16 S$ rDNA sequence analysis}

The 16S rRNA sequence analysis showed that strain SL6 $^{\mathrm{T}}$ always clustered together with all other cultivated members of the genus Thermodesulfobacterium. 


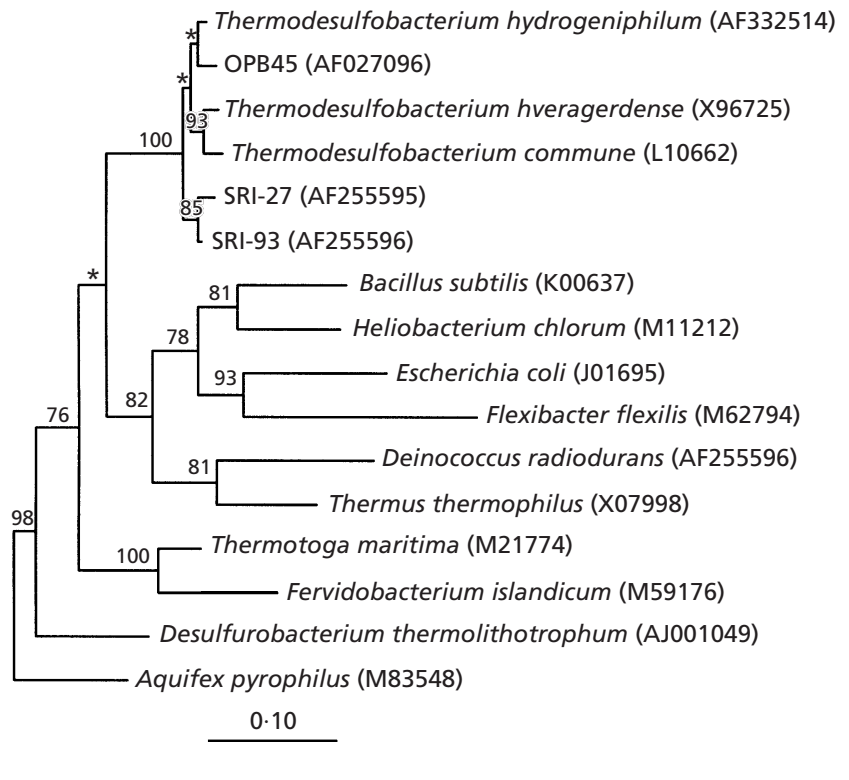

Fig. 3. Phylogenetic tree showing the position of Thermodesulfobacterium hydrogeniphilum $\mathrm{SLG}^{\top}$. The tree was generated using maximum-likelihood analysis. The scale bar represents the number of fixed mutations per nucleotide position. The numbers at the branch nodes are bootstrap values based on 100 bootstrap trees (bootstrap values below 50 are represented by asterisks).

Strain SL6 ${ }^{\mathrm{T}}$ was more closely related to OPB45 $(97 \cdot 2 \%$ similarity), an environmental clone sequence obtained from a hot spring at Yellowstone National Park (Hugenholtz et al., 1998) (Fig. 3). It also placed strain SL6 ${ }^{\mathrm{T}}$ as a close relative of Thermodesulfobacterium commune YSRA-1 ${ }^{\mathrm{T}}(96.8 \%$ similarity) and Thermodesulfobacterium hveragerdense $\mathrm{JSP}^{\mathrm{T}}(96 \cdot 2 \%$ similarity). Lower similarity values were obtained with environmental clone sequences SRI-93 (96.0\%) and SRI-27 (95.1\%), retrieved from hot-spring microbial mats (Skirnisdottir et al., 2000).

Strains SL6 ${ }^{\mathrm{T}}$ and OPB45 clustered together in $38 \%$ of the bootstrap trees. However, because of the similarity of all the 16S rRNA sequences in the Thermodesulfobacterium group, it was difficult to resolve this association, and other phylogenetic methods did not result in higher bootstrap values. Our results confirmed that the overall position of the Thermodesulfobacterium group and Thermotogales is not clearly resolved. The Thermotogales most often branched more deeply than the Thermodesulfobacterium group (39 of 100 bootstrap resamplings), or the two orders grouped together (36 of 100 bootstrap trees); occasionally, the Thermodesulfobacterium group branched more deeply than the Thermotogales (11 of the 100 bootstrap trees).

\section{Ecological relevance}

Prior to this report, Thermodesulfobacterium species had been isolated only from terrestrial hot springs (Zeikus et al., 1983; Sonne-Hansen \& Ahring, 1999) and oil reservoirs (Rozanova \& Khudyakova, 1974; Christensen et al., 1992; L'Haridon et al., 1995). Here, we provide the description of the first organism belonging to this genus to be isolated from a marine environment and, more specifically, from a deep-sea hydrothermal vent site at Guaymas Basin. Its substrates (hydrogen, $\mathrm{CO}_{2}$, sulfate) are commonly found in hydrothermal fluids and the surrounding sea water (Jannasch \& Mottl, 1985). Acetate, which stimulates the growth of strain SL6 ${ }^{\mathrm{T}}$ in the presence of these substrates, is also present at Guaymas Basin hydrothermal vent sites (Martens, 1990). Since the optimal range of temperatures for growth of strain SL6 ${ }^{\mathrm{T}}$ $\left(60-75^{\circ} \mathrm{C}\right)$ covers the temperature range for which sulfate reduction has been measured in sediment slurries collected at Guaymas Basin (Jørgensen et al., 1990), it appears that strain SL6 ${ }^{\mathrm{T}}$ may contribute to primary production at these sites.

\section{Taxonomic position}

When a number of different taxonomic parameters were compared, strain SL6 ${ }^{\mathrm{T}}$ differed from the three described Thermodesulfobacterium species (Table 1). The novel isolate differs from them in its salinity range and optimum for growth, in its chemolithoautotrophic mode of life and in its inability to reduce thiosulfate. Its physiological properties, in combination with the results of the $16 \mathrm{~S}$ rRNA gene sequence comparison, indicate that strain $\mathrm{SL6}^{\mathrm{T}}$ represents a novel species within the genus Thermodesulfobacterium. We propose to name this novel species Thermodesulfobacterium hydrogeniphilum sp. nov., with strain $\mathrm{SL}^{\mathrm{T}}$ as the type strain.

According to the description of the genus Thermodesulfobacterium by Zeikus et al. (1983), its members are chemo-organotrophic, fermentative sulfatereducers that use lactate, pyruvate and hydrogen as electron donors and sulfate and thiosulfate as electron acceptors for growth. However, Thermodesulfobacterium hydrogeniphilum is a chemolithoautotrophic organism unable to support a fermentative metabolism and unable to use thiosulfate as an electron acceptor. Since the most recent description of the genus (Hatchikian \& Ollivier, 2001) is also not in agreement with the phenotypic characteristics of Thermodesulfobacterium hveragerdense and Thermodesulfobacterium hydrogeniphilum, we propose that the description of the genus Thermodesulfobacterium should be emended as described below.

\section{Emended description of the genus Thermodesulfobacterium}

Straight, rod-shaped cells, approximately $0 \cdot 3-2 \cdot 8 \mu \mathrm{m}$ in size, occurring singly, in pairs or in chains. Possess an outer wall membrane layer. Gram-negative. Cells may form 'blebs' at their ends. Contain non-phytanyl ether-linked lipids, cytochrome $c_{3}$ and desulfofuscidin but no desulfoviridin. Thermophilic. Strict anaerobes 
Table 1. Main characteristics of cultivated members of the genus Thermodesulfobacterium

Data were obtained from Rozanova \& Pivovarova (1988), Zeikus et al. (1983) and Sonne-Hansen \& Ahring (1999). Electron donors were tested with $\mathrm{CO}_{2}$ as the carbon source. All taxa used $\mathrm{H}_{2}+$ acetate $(2 \mathrm{mM})$ as an electron donor. $(+)$, Slight growth; ND, not determined.

\begin{tabular}{|c|c|c|c|c|}
\hline Characteristic & Strain SL6 $^{\mathrm{T}}$ & T. commune & T. thermophilum & T. hveragerdense \\
\hline Cell size $(\mu \mathrm{m})$ & $0.4-0.5 \times 0.5-0.8$ & $0.3 \times 0.9$ & $0.6 \times 2 \cdot 0$ & $0.5 \times 2 \cdot 8$ \\
\hline Motility/flagellation & $+/$ Single polar & - & $+/$ Single polar & - \\
\hline $\mathrm{G}+\mathrm{C}$ content $(\mathrm{mol} \%)$ & 28 & 34 & $38(31)^{*}$ & 40 \\
\hline Optimal salinity $\left(\mathrm{g} \mathrm{l}^{-1}\right)$ & 30 & 0 & 1 & 0 \\
\hline Optimal temperature $\left({ }^{\circ} \mathrm{C}\right)$ & 75 & 70 & 65 & $70-74$ \\
\hline \multicolumn{5}{|l|}{ Electron donors: } \\
\hline $\mathrm{H}_{2}$ & $+\dagger$ & - & - & - \\
\hline Formate & - & ND & + & - \\
\hline Lactate & - & + & + & + \\
\hline Pyruvate & - & + & + & + \\
\hline \multicolumn{5}{|l|}{ Fermentation of: } \\
\hline Pyruvate & - & + & + & + \\
\hline Lactate & - & - & $(+)$ & - \\
\hline \multicolumn{5}{|l|}{ Electron acceptors: } \\
\hline Thiosulfate & - & + & + & + \\
\hline Sulfite & - & - & + & + \\
\hline
\end{tabular}

* The value in parentheses was determined by Henry et al. (1994).

$\dagger$ Autotrophic growth.

that use sulfate as electron acceptor; the sulfate is reduced to sulfide. Nutritionally versatile (chemoorganotrophic or chemolithoautotrophic). Acetate (1-2 mM) may be required for growth with $\mathrm{H}_{2}$ and $\mathrm{CO}_{2}$ in the presence of sulfate. Occurs in thermal environments including hot springs, hot oil reservoirs and deep-sea hydrothermal vents. The $\mathrm{G}+\mathrm{C}$ content of the DNA is between 28 and $40 \mathrm{~mol} \%$. The type species is Thermodesulfobacterium commune.

\section{Description of Thermodesulfobacterium hydrogeniphilum sp. nov.}

Thermodesulfobacterium hydrogeniphilum (hy.dro.ge. ni.phi'lum. N.L. n. hydrogenum hydrogen; Gr. n. philos friend; N.L. adj. hydrogeniphilum hydrogenliking, since growth depends upon the presence of hydrogen).

Each cell is highly motile by means of a single polar flagellum. Cells occur singly and in pairs and are $0.5-0.8 \mu \mathrm{m}$ long by $0.4-0.5 \mu \mathrm{m}$ wide. Growth occurs between 50 and $80^{\circ} \mathrm{C}$, the optimum being approximately $75^{\circ} \mathrm{C}$ (doubling time $186 \mathrm{~min}$ ). Growth occurs between $\mathrm{pH} 6.3$ and 6.8 , the optimum being approximately $\mathrm{pH} 6 \cdot 5$, and at $\mathrm{NaCl}$ concentrations ranging from 5 to $55 \mathrm{~g}^{-1}$, the optimum being approximately $30 \mathrm{~g}^{-1}$. Strictly chemolithoautotrophic. Sulfate serves as an electron acceptor in the presence of $\mathrm{H}_{2}$. In the presence of $\mathrm{H}_{2}, \mathrm{CO}_{2}$ and sulfate, acetate, fumarate, 3- methylbutyrate, glutamate, yeast extract, peptone and tryptone stimulate growth. Sulfur, thiosulfate, sulfite, cystine, fumarate and nitrate are not used as electron acceptors. Growth is inhibited by ampicillin, chloramphenicol and rifampicin at $25 \mu \mathrm{g} \mathrm{ml}^{-1}$. Growth occurs in the presence of tetracycline at $25 \mu \mathrm{g} \mathrm{m}^{-1}$, penicillin $\mathrm{G}$ at $100 \mu \mathrm{g} \mathrm{ml}^{-1}$, streptomycin at $200 \mu \mathrm{g} \mathrm{m} \mathrm{m}^{-1}$ and kanamycin at $200 \mu \mathrm{g} \mathrm{ml}^{-1}$. The $\mathrm{G}+\mathrm{C}$ content of the DNA of the type strain is $28 \mathrm{~mol} \%$ (thermal denaturation method).

The type strain is $\mathrm{SL6}^{\mathrm{T}}\left(=\mathrm{DSM} 14290^{\mathrm{T}}=\mathrm{JCM}\right.$ $11239^{\mathrm{T}}$ ), which was obtained from deep-sea hydrothermal vent sulfides at Guaymas Basin.

\section{ACKNOWLEDGEMENTS}

The Guaynaut cruise was organized by IFREMER (A.-M. Alayse, Chief Scientist). We thank the Captain and crew of NO Le Nadir, the pilots of the DSV Nautile for skilful operations and the support crew. This work was supported by GDR 1006 CNRS/Ifremer, the MASTIII programme from the EU (contract no. CT95-0034) and by a National Science Foundation-LexEn grant (OCE no. 9729784) to A. L. R.

\section{REFERENCES}

Beeder, J., Nilsen, R. K., Rosnes, J. T., Torsvik, T. \& Lien, T. (1994). Archaeoglobus fulgidus isolated from hot North Sea oil field waters. Appl Environ Microbiol 60, 1227-1231. 
Beeder, J., Torsvik, T. \& Lien, T. (1995). Thermodesulforhabdus norvegicus gen. nov., sp. nov., a novel thermophilic sulfate-reducing bacterium from oil field water. Arch Microbiol 164, 331-336.

Brosius, J., Palmer, M. L., Kennedy, P. J. \& Noller, H. F. (1978). Complete nucleotide sequence of a $16 \mathrm{~S}$ ribosomal RNA gene from Escherichia coli. Proc Natl Acad Sci U S A 75, 4801-4805.

Burggraf, S., Jannasch, H. W., Nicolaus, B. \& Stetter, K. O. (1990). Archaeoglobus profundus sp. nov., represents a new species within the sulfur-reducing Archaebacteria. Syst Appl Microbiol 13, 24-28.

Castro, H. F., Williams, N. H. \& Ogram, A. (2000). Phylogeny of sulfate-reducing bacteria. FEMS Microbiol Ecol 31, 1-9.

Charbonnier, F. \& Forterre, P. (1994). Comparison of plasmid DNA topology among mesophilic and thermophilic eubacteria and archaebacteria. J Bacteriol 176, 1251-1259.

Christensen, B., Torsvik, T. \& Lien, T. (1992). Immunomagnetically captured thermophilic sulfate-reducing bacteria from North Sea oil field waters. Appl Environ Microbiol 58, 1244-1248.

Conn, H. J., Bartholomew, J. W. \& Jennison, M. W. (1957). Staining methods. In Manual of Microbial Methods, pp. 30-36. Edited by Society of American Bacteriologists. New York: McGraw-Hill.

De Soete, G. (1983). A least squares algorithm for fitting additive trees to proximity data. Psychometrika 48, 621-626.

De Vos, P. \& Trüper, H. G. (2000). Judicial Commission of the International Committee on Systematic Bacteriology. IXth International (IUMS) Congress of Bacteriology and Applied Microbiology. Minutes of the meetings, 14, 15 and 18 August 1999, Sydney, Australia. Int J Syst Evol Microbiol 50, 2239-2244.

Hatchikian, E. C. \& Ollivier, B. (2001). Genus I. Thermodesulfobacterium. In Bergey's Manual of Systematic Bacteriology, 2nd edn, vol. 1, pp. 390-393. Edited by G. M. Garrity. New York: Springer.

Henry, E. A., Devereux, R., Maki, J. S., Gilmour, C. C., Woese, C. R., Mandelco, L., Schauder, R., Remsen, C. C. \& Mitchell, R. (1994). Characterization of a new thermophilic sulfate-reducing bacterium Thermodesulfovibrio yellowstonii, gen. nov. and sp. nov.: its phylogenetic relationship to Thermodesulfobacterium commune and their origins deep within the bacterial domain. Arch Microbiol 161, 62-69.

Hobbie, J. E., Daley, R. J. \& Jasper, S. (1977). Use of nuclepore filters for counting bacteria by fluorescence microscopy. Appl Environ Microbiol 33, 1225-1228.

Huber, H., Jannasch, H., Rachel, R., Fuchs, T. \& Stetter, K. O. (1997). Archaeoglobus veneficus sp. nov., a novel facultative chemolithoautotrophic hyperthermophilic sulfite reducer, isolated from abyssal black smokers. Syst Appl Microbiol 20, 374-380.

Hugenholtz, P., Pitulle, P., Hershberger, K. L. \& Pace, N. R. (1998). Novel division level bacterial diversity in a Yellowstone hot spring. J Bacteriol 180, 366-376.

Jannasch, H. W. \& Mottl, J. (1985). Geomicrobiology of deep-sea hydrothermal vents. Science 229, 717-725.

Jeanthon, C., L'Haridon, S., Pradel, N. \& Prieur, D. (1999). Rapid identification of hyperthermophilic methanococci isolated from deepsea hydrothermal vents. Int J Syst Bacteriol 49, 591-594.

Jørgensen, B. B., Zawacki, L. X. \& Jannasch, H. W. (1990). Thermophilic bacterial sulfate reduction in deep-sea sediments at the Guaymas Basin hydrothermal vent site (Gulf of California). Deep-Sea Res 37, 695-710.

L'Haridon, S., Reysenbach, A. L., Glénat, P., Prieur, D. \& Jeanthon, C. (1995). Hot subterranean biosphere in a continental oil reservoir. Nature 377, 223-224.

Maidak, B. L., Cole, J. R., Parker, C. T, Jr \& 11 other authors (1999). A new version of the RDP (Ribosomal Database Project). Nucleic Acids Res 27, 171-173.

Marmur, J. \& Doty, D. (1962). Determination of the base composition of deoxyribonucleic acid from its thermal denaturation temperature. J Mol Biol 5, 109-118.

Martens, C. (1990). Generation of short chain organic acid anions in hydrothermally altered sediments of the Guaymas Basin, Gulf of California. Appl Geochem 5, 71-76.
Miller, T. L. \& Wolin, M. J. (1974). A serum bottle modification of Hungate technique for cultivating obligate anaerobes. Appl Environ Microbiol 27, 985-987.

Nilsen, R. K., Torsvik, T. \& Lien, T. (1996). Desulfotomaculum thermocisternum sp. nov., a sulfate reducer isolated from a hot North Sea oil reservoir. Int J Syst Bacteriol 46, 397-402.

Olsen, G. J., Matsuda, H., Hagstrom, R. \& Overbeek, R. (1994a). fastDNAmL: a tool for construction of phylogenetic trees of DNA sequences using maximum likelihood. Comput Appl Biosci 10, 41-48.

Olsen, G. J., Woese, C. R. \& Overbeek, R. (1994b). The winds of (evolutionary) change: breathing new life into microbiology. J Bacteriol 176, 1-6.

Pfennig, N., Widdel, F. \& Trüper, H. G. (1981). The dissimilatory sulfate-reducing bacteria. In The Prokaryotes, 2nd edn, pp. 926-940. Edited by M. Starr, H. Stolp, H. G. Trüper, A. Balows \& H. G. Schlegel. New York: Springer.

Postgate, J. (1959). A diagnostic reaction of Desulphovibrio desulphuricans. Nature 14, 481-482.

Rees, G. N., Grassia, G. S., Sheehy, A. J., Dwivedi, P. P. \& Patel, B. K. C. (1995). Desulfacinum infernum gen. nov., sp. nov., a thermophilic sulfate-reducing bacterium from a petroleum reservoir. Int $J$ Syst Bacteriol 45, 85-89.

Rozanova, E. P. \& Khudyakova, A. I. (1974). A new non-sporeforming thermophilic sulfate-reducing organism, Desulfovibrio thermophilus nov. sp. Microbiology (English translation of Mikrobiologiya) 43, 908-912.

Rozanova, E. P. \& Pivovarova, T. A. (1988). Reclassification of Desulfovibrio thermophilus (Rozanova and Khudyakova, 1974). Microbiology (English translation of Mikrobiologiya) 57, 102-106.

Rueter, P., Rabus, R., Wilkes, H., Aeckersberg, F., Rainey, F. A., Jannasch, H. W. \& Widdel, F. (1994). Anaerobic oxidation of hydrocarbons in crude oil by new types of sulphate-reducing bacteria. Nature 372, 455-458.

Sambrook, J., Fritch, E. F. \& Maniatis, T. (1989). Molecular Cloning: a Laboratory Manual, 2nd edn. Cold Spring Harbor, NY: Cold Spring Harbor Laboratory.

Sievert, S. M. \& Kuever, J. (2000). Desulfacinum hydrothermale sp. nov., a thermophilic, sulfate-reducing bacterium from geothermally heated sediments near Milos Island (Greece). Int J Syst Evol Microbiol 50, 1239-1246.

Skirnisdottir, S., Hreggvidsson, G. O., Hjorleifsdottir, S., Marteinsson, V. T., Petursdottir, S. K., Holst, O. \& Kristjansson, J. K. (2000). Influence of sulfide and temperature on species composition and community structure of hot spring microbial mats. Appl Environ Microbiol 66, 2835-2841.

Sonne-Hansen, J. \& Ahring, B. K. (1999). Thermodesulfobacterium hveragerdense sp. nov., and Thermodesulfovibrio islandicus sp. nov., two thermophilic sulfate reducing bacteria isolated from a Icelandic hot spring. Syst Appl Microbiol 22, 559-564.

Stetter, K. O. (1988). Archaeoglobus fulgidus gen. nov., sp. nov. : a new taxon of extremely thermophilic Archaebacteria. Syst Appl Microbiol 10, 172-173.

Stetter, K. O. (1992). The genus Archaeoglobus. In The Prokaryotes, 2nd edn, pp. 707-711. Edited by A. Balows, H. G. Trüper, M. Dworkin, W. Harder \& K. H. Schleifer. New York: Springer.

Stetter, K. O., Lauerer, G., Thomm, M. \& Neuner, A. (1987). Isolation of extremely thermophilic sulfate reducers: evidence for a novel branch of archaea. Science 236, 822-824.

Stetter, K. O., Huber, R., Blochl, E., Kurr, M., Eden, R. D., Fielder, M., Cash, H. \& Vance, I. (1993). Hyperthermophilic archaea are thriving in deep North Sea and Alaskan oil reservoirs. Nature 365, 743-745.

Tao, T.-S., Yue, Y.-Y. \& Fang, C.-X. (1996). Irregularities in the validation of the genus Thermodesulfobacterium and its species. Request for an opinion. Int J Syst Bacteriol 46, 622. 
Widdel, F. (1992). The genus Thermodesulfobacterium. In The Prokaryotes, 2nd edn, pp. 3390-3392. Edited by A. Balows, H. G. Trüper, M. Dworkin, W. Harder \& K. H. Schleifer. New York: Springer.

Widdel, F. \& Bak, F. (1992). Gram-negative mesophilic sulfatereducing bacteria. In The Prokaryotes, 2nd edn, pp. 3352-3378. Edited by A. Balows, H. G. Trüper, M. Dworkin, W. Harder \& K. H. Schleifer. New York: Springer.

Zeikus, J. G., Dawson, M. A., Thompson, T. E., Ingvorsen, K. \& Hatchikian, E. C. (1983). Microbial ecology of volcanic sulphidogenesis: isolation and characterization of Thermodesulfobacterium commune gen. nov. and sp. nov. J Gen Microbiol 129, 1159-1169. 